\title{
A New Assay for Cystic Fibrosis Factor: Effects of Sera from Patients with Cystic Fibrosis in the in Vitro Electrical Properties of Rat Jejunum
}

\author{
HIROSHI ARAKI, MICHAEL FIELD, AND HARRY SHWACHMAN ${ }^{(16)}$ \\ Department of Medicine (Clinical Nutrition), The Children's Hospital Medical Center, Department of Medicine, \\ Beth Israel Hospital, and Departments of Pediatrics and Medicine, Harvard Medical School.
}

Boston. Massachusetts, USA

\section{Extract}

The in vitro electrical properties of rat jejunum were utilized to assay a factor or factors in serum from patients with cystic fibrosis (CF). Sera from patients with CF were found to decrease short circuit current (SCC) and the SCC response to glucose, and to increase electrical resistance.

These effects were present in all 24 patients with $\mathrm{CF}$ and 10 of 14 parents of CF patients and absent from the serum of 21 control subjects. This quantitative technique provides an alternative to the ciliostatic assays for the detection of the CF factor or factors.

\section{Speculation}

This technique may provide a good model system for assaying tissues for the presence of the CF factor. It may prove of invaluable assistance to the geneticist in providing meaningful counseling, especially to unaffected siblings of patients with CF. Perhaps what we are measuring is the effect of one or more factors, variously called the Spock factor, ciliotoxic factor, or Mangos factor.

There have been conflicting observations on the effects of $\mathrm{CF}$ factor or factors on intestinal transport processes. Brown et al. (5) demonstrated that serum, sweat, and saliva from patients with $\mathrm{CF}$ inhibit the transport of the glucose analog arbutin, into rat jejunal tissue and suggested that this inhibition was secondary to a reduction in sodium transport. Morine et al. (9) reported reduced uptake of L-alanine and cycloleucine by rat jejunal rings after preincubation with diluted CF saliva or serum. Taussig and Gardner (12), however, could not demonstrate any effect of $\mathrm{CF}$ saliva on $\mathrm{Na}$ absorption by rat jejunum. They also found no effect of CF saliva or plasma on the uptake of L-alanine or 3-O-methyl glucose.

The present experiments were undertaken to re-examine the question of whether $\mathrm{CF}$ serum inhibits intestinal transport processes and, if so, to attempt to establish a quantitative assay of the inhibitory effect. For these purposes we have utilized the electrica properties of rat jejunum clamped in an Ussing chamber $(10,13)$.

\section{METHODS}

Rats of Sprague-Dawley strain weighing 200-250 g were maintained on a standard commercial diet and water ad libitum. Rats were killed with intraperitoneal pentobarbital. A segment of jejunum was excised, rinsed free of intestinal contents, opened along the mesenteric border, and clamped as a flat sheet between two lucite half-chambers (1). The surface area of the exposed in testine was about $0.8 \mathrm{~cm}^{2}$. Tissues were bathed in a $\mathrm{K}$ rebs-Ringer solution with the following compositions in milliequivalents per liter: $\mathrm{Na} 145.0 ; \mathrm{K}$ 6.0; $\mathrm{Ca} 1.25 ; \mathrm{Mg} 2.5 ; \mathrm{Cl} 126.5 ; \mathrm{SO}_{4} 2.5 ; \mathrm{HPO}_{4}$
1.0; $\mathrm{HCO}_{3} 25.0$. The perfusate was kept at $37^{\circ}$, constantly gassec with $5 \% \mathrm{CO}_{2}-95 \% \mathrm{O}_{2}$ and circulated by gas-lift. The transmura potential difference (PD) was continously monitored for 60-70 mir and the total resistance between the tips of the PD bridges wa: determined at 5 -min intervals by passing a direct current via ar external circuit and recording the resulting change in PD. Mem. brane resistance was calculated as the difference between tota resistance and the fluid resistance, the latter determined before mounting tissues. The SCC was calculated as PD divided by membrane resistance (1). Serum was diluted 1:3 (v/v) with Ringer solution and added to the serosal reservoir just before mounting tissues. Sera were obtained from 24 patients with CF, 21 healthy subjects, and 14 heterozygotes (healthy parents of CF patients). Most sera were tested within $3 \mathrm{hr}$ after blood was drawn and all sera were tested within 4 days. Sera were maintained at $4^{\circ}$ until assayed. The ionic concentrations of the $\mathrm{CF}$ sera $(\mathrm{Na}, \mathrm{K}, \mathrm{Cl})$ were found not to differ significantly from those of control sera. The sera were assayed blindly.

\section{RESULTS}

Table 1 summarizes electrical measurements made $30 \mathrm{~min}$ after mounting tissues and exposure to serum. Results are shown in a variety of bathing solutions. It can be seen that in both glucose concentrations of bathing solutions, native CF sera decreased SCC and increased resistance, whereas native control sera did not alter them. Furthermore, when sera were first heated to $56^{\circ}$ for $30 \mathrm{~min}$, this effect almost completely disappeared in the presence of 11 $\mathrm{mM}$ glucose. In the presence of $25 \mathrm{mM}$ glucose, SCC developed in the tissues treated with heated CF sera was significantly less than that in control sera-treated tissues. Figure I shows SCC measurements plotted at 5-min intervals. Measurements were made in the presence of $11 \mathrm{mM}$ glucose on both sides of the tissue. CF sera (O) produced the lowest currents. When CF sera were heated $\left(56^{\circ}\right.$ for $30 \mathrm{~min}$ before assay, the SCC ( approached the values obtained without sera and with control sera, but was significantly less than that with heated control sera at all times after $10 \mathrm{~min}$. Normal sera had no effect on SCC. However, heated normal sera significantly increased SCC obtained with native normal sera, particularly during the interval from 15 to $40 \mathrm{~min}$. Figure 2 shows changes in electrical resistance as measured at 5-min intervals. CF sera increased resistance, whereas normal sera did not. Heated $\mathrm{CF}$ serum $\left(56^{\circ}, 30 \mathrm{~min}\right)$ also did not increase resistance. Figure 3 compares the SCC of CF and normal sera-treated tissues in the presence of fructose in the luminal bathing medium over a period of $40 \mathrm{~min}$. Fructose $(11 \mathrm{mM})$ was replaced by glucose $(11 \mathrm{mM})$ at $40 \mathrm{~min}$. The results represent the mean values of five separate experiments. CF serum decreased SCC when either fructose (which is not actively transported) or glucose was present in the luminal bathing medium. Furthermore, when glucose was substi- 
Table 1. Comparison of effects of glucose and cystic fibrosis $(C F)$ serum on electrical properties of rat jejunum ${ }^{1}$

\begin{tabular}{|c|c|c|c|}
\hline & $\mathrm{PD}, \mathrm{mV}$ & Resistance, $\mathrm{ohm} \cdot \mathrm{cm}^{2}$ & $\begin{array}{c}\text { Short circuit current } \\
\left(\mu \mathrm{A} / \mathrm{cm}^{2}\right), \\
1,000 \times \mathrm{PD} / \mathrm{R}\end{array}$ \\
\hline Glucose free & $2.3 \pm 0.2(5)$ & $36.3 \pm 3.6(5)$ & $65.8 \pm 9.9(5)$ \\
\hline $11 \mathrm{mM}$ glucose & $5.0 \pm 0.1(12)$ & $43.2 \pm 1.4(12)$ & $119.4 \pm 6.9(12)$ \\
\hline $25 \mathrm{mM}$ glucose & $8.1 \pm 0.5(3)$ & $42.8 \pm 2.3(3)$ & $192.7 \pm 11.1(3)$ \\
\hline Native normal serum, $11 \mathrm{mM}$ glucose & $5.6 \pm 0.2(11)$ & $47.2 \pm 1.7(11)$ & $121.5 \pm 5.7(11)$ \\
\hline Heated normal serum, $11 \mathrm{mM}$ glucose & $5.6 \pm 0.1(6)$ & $40.3 \pm 1.7(6)$ & $139.9 \pm 5.7(6)$ \\
\hline Native CF serum, $11 \mathrm{mM}$ glucose & $3.7 \pm 0.2(13)$ & $60.4 \pm 3.7(13)$ & $01.5 \pm 4.5(13)$ \\
\hline Heated $C F$ serum, $11 \mathrm{mM}$ glucose & $5.2 \pm 0.4(6)$ & $46.0 \pm 2.6(6)$ & $109.2 \pm 8.8(6)$ \\
\hline Native normal serum, $25 \mathrm{mM}$ glucose & $8.1 \pm 0.2(6)$ & $40.2 \pm 1.4(6)$ & $203.8 \pm 6.5(6)$ \\
\hline Heated normal serum, $25 \mathrm{mM}$ glucose & $8.1 \pm 0.3(3)$ & $40.7 \pm 1.6(3)$ & $199.7 \pm 12.9(3)$ \\
\hline Native CF serum, $25 \mathrm{mM}$ glucose & $6.6 \pm 0.4(10)$ & $61.1 \pm 3.9(10)$ & $95.6 \pm 6.2(10)$ \\
\hline Heated CF serum, $25 \mathrm{mM}$ glucose & $6.9 \pm 0.8(5)$ & $46.5 \pm 2.3(5)$ & $141.0 \pm 17.0(5)$ \\
\hline
\end{tabular}

${ }^{1}$ Measurements were made 30 min after mounting tissues in chambers. Sera were added to the serosal bathing solutions just before the mounting of ues. The values are mean and SEM. Within parentheses are the number of experiments. PD: transmural potential difference.

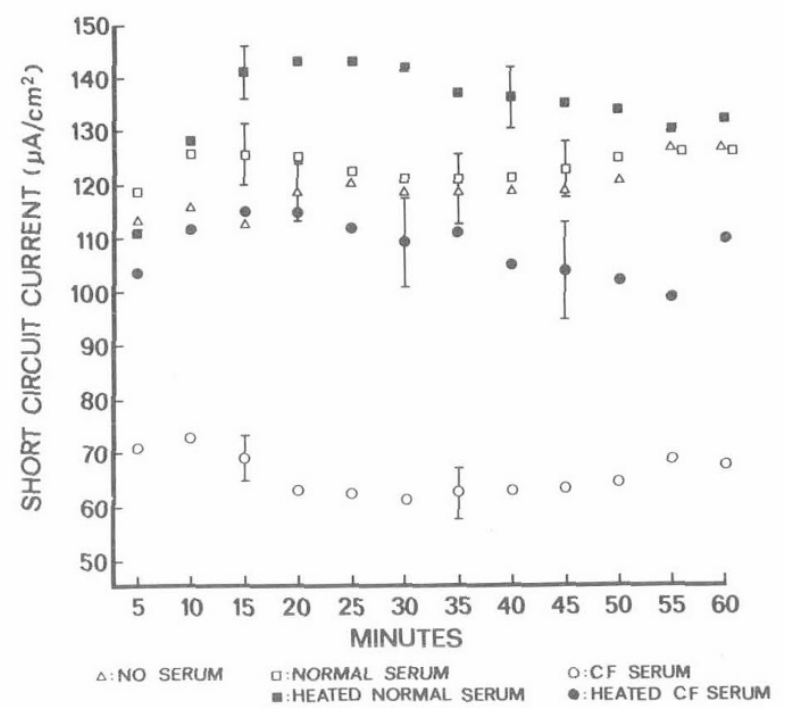

Fig. 1. Effects of sera on short circuit current. Glucose ( $11 \mathrm{mM})$ present $n$ both luminal and serosal bathing solutions. Values shown are means for he following numbers of experiments: cystic fibrosis $(C F)$ 13; control 10; leated CF 6; heated control 6; no serum 6. The brackets indicate \pm SEM.

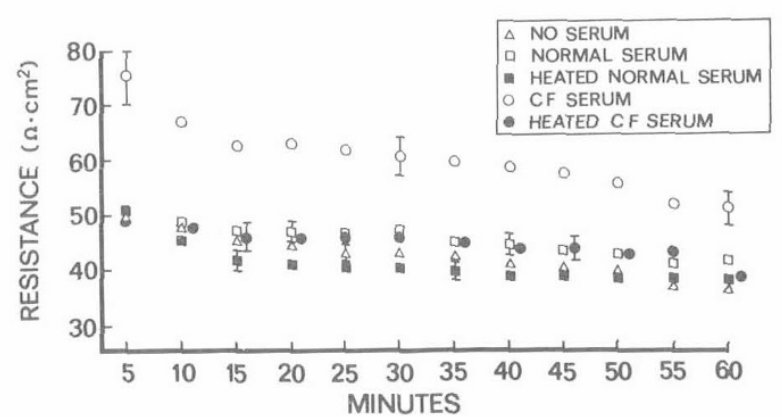

Fig. 2. Effects of sera on electrical resistance. See legend to Figure 1 for details. $C F$ : cystic fibrosis.

tuted for fructose, an increase in SCC developed in both normal tissues and in CF serum-treated tissues. This increase was greater with the normal serum than the CF serum. The higher electrical resistance of CF serum-treated tissues was apparent in fructose as well as glucose-Ringer.

In order to ascertain whether or not the observed changes in electrical properties were caused by the presence in serum of drugs used in therapy we studied the following: four newly diagnosed

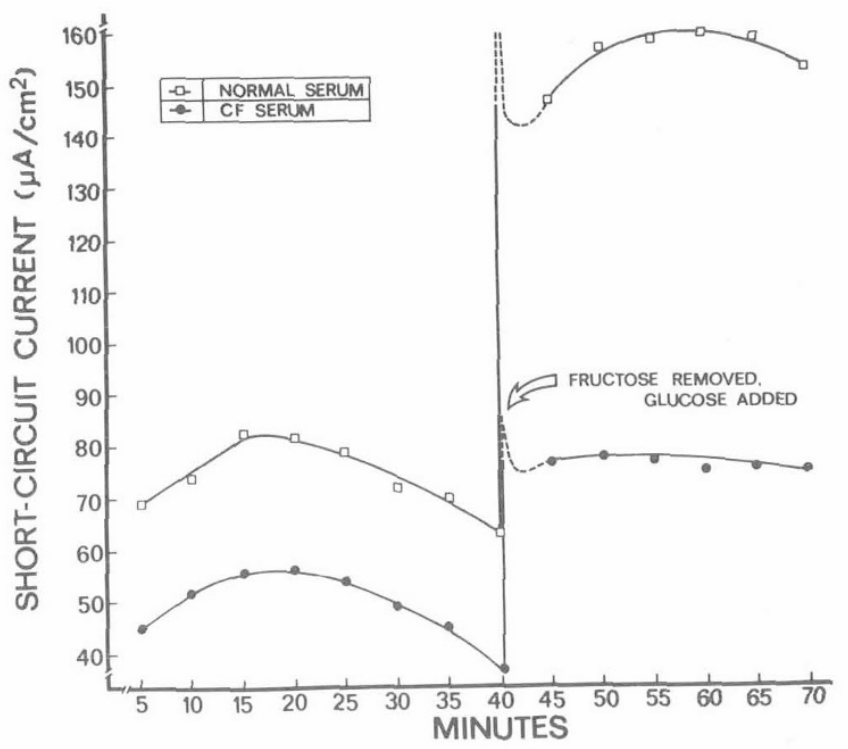

Fig. 3. Effects of sera on short circuit current in the presence and absence of glucose on the luminal side. Sera from five cystic fibrosis $(C F)$ patients and five control subjects were tested. Fructose $(11 \mathrm{mM})$ on the luminal side was replaced with glucose $(11 \mathrm{mM})$ at $40 \mathrm{~min}$. Glucose (11 $\mathrm{mM}$ ) was present on the serosal side throughout.

patients with $\mathrm{CF}$, two patients with $\mathrm{CF}$ who received oral antibiotics and no Viokase, and one patient with CF who was treated only with Viokase and no antibiotics. Sera from these patients yielded the same results as shown for CF sera in Figures 1 and 2. Thus agents used in therapy do not appear to influence the findings.

Sera from 14 parents of patients with $\mathrm{CF}$ were also studied. In Figure 4 , the SCC of tissues treated by these sera are compared with SCC of control and CF serum-treated tissues. In 4 of the 14 parents, no effect on SCC was observed and 10 showed the same reduction in SCC noted in patients with CF. Sera were collected again from all four heterozygotes that had given negative results previously and were assayed in a more concentrated form (1 part serum to 1 part Ringer instead of 1:3). These sera now gave results in the $\mathrm{CF}$ range. In contrast, four normal sera diluted 1:1 gave the same results as when diluted 1:3.

\section{DISCUSSION}

Spock et al. (11) reported that sera from patients and from many, but not all, heterozygotes for CF produce dyskinesia of 


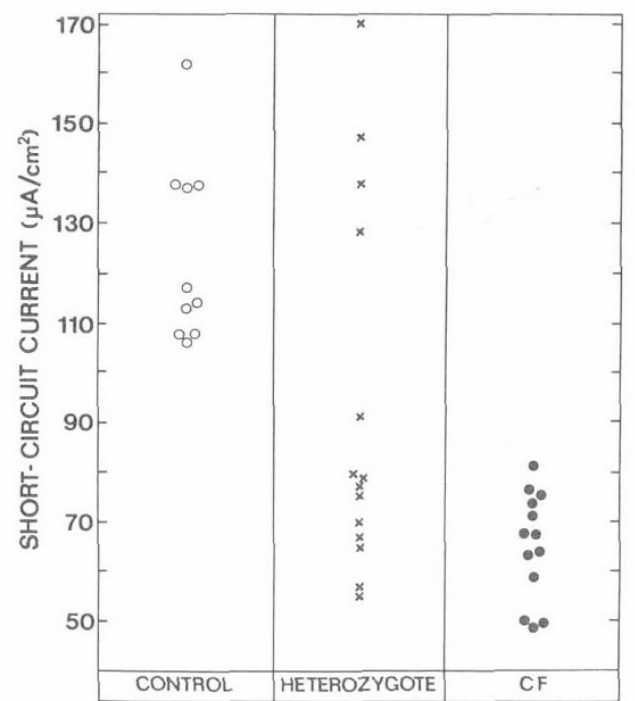

Fig. 4. The short circuit current of tissues treated with control sera (10 experiments) heterozygous sera (14 experiments), or cystic fibrosis $(C F)$ sera (13 experiments). The values shown were determined $30 \mathrm{~min}$ after exposure to sera. Glucose (11 mM) was present in both luminal and serosal bathing solutions.

ciliary activity when placed on rabbit tracheal explants. This "ciliotoxic factor" has also been detected in saliva and in media of cultured cells from patients with CF and heterozygotes for CF (2, 3). Using the oyster cilia assay, Bowman and her associates (4) found that the ciliotoxic factor is a heat-labile substance with molecular weight between 1,000 and 10,000 which is associated on immunoelectrophoresis with immunoglobulin $G_{1}$. The oyster cilia method of Lockhart and Bowman (7) appears to be the quickest and least expensive assay technique described thus far. Sera from heterozygotes and homozygotes were found to stop ciliary action in less than $30 \mathrm{~min}$, whereas control sera did not. This assay technique is subject to seasonal and other variations, however, and a number of laboratories have been unable to obtain reproducible results. Furthermore, changes in ciliary motion are not readily quantitated. For these reasons, a more reliable and quantifiable assay technique would be desirable.

The present study demonstrates that CF serum has a substance which is heat labile, reduces SCC, and increases electrical resistance when added to the serosal side of rat jejunum in an Ussing chamber. The inhibitory effect on SCC was greater when glucose was present in the luminal side than when it was absent. suggesting that the reduction in SCC is in part attributable to inhibition of glucose-dependent $\mathrm{Na}$ Transport.

The higher electrical resistance of $\mathrm{CF}$ serum-treated tissues suggests that the CF factor also decreases passive permeability to ions. Although $\mathrm{CF}$ factor may inhibit active $\mathrm{Na}$ transport, as suggested by others (7), it is unlikely that this effect would by itself cause the observed increase in electrical resistance. The stimulation of active $\mathrm{Na}$ transport by glucose did not lower resistance (data not shown), suggesting that changes in $\mathrm{Na}$ transport have little effect on total resistance.

Although many questions remain to be resolved, this study demonstrates that the electrical properties of rat jejunum provide a good model system for investigating factor or factors in serum (and other fluids) from CF patients which affect membran transport. Since the CF serum effect on SCC is quickly apparer (Fig. 1), it may prove feasible to use each tissue as its own contre by first recording the base line SCC and then adding serum Preliminary experiments indicate, however, that the effect of $\mathrm{C}$ serum is less pronounced when added to the serosal bathin medium 10 min after mounting tissues than when added at the tim of mounting. In contrast, changes of the magnitude shown in Tabl 1 occur when CF serum is added to the luminal bathing medium 1 min after mounting tissues. The differences that develop wit immediate as opposed to delayed addition of serum and witl luminal as opposed to serosal additions are currently bein: explored.

\section{SUMMARY}

The effect of serum from patients with CF and heterozygotes fo $\mathrm{CF}$ were tested blindly by utilizing a modified Ussing chambe technique. These sera affected the electrical properties in ra jejunum. These sera increased resistance and markedly decreasec SCC whereas control sera did not change them. When CF sera were heated $\left(56^{\circ}\right.$ for $\left.30 \mathrm{~min}\right)$ before assay the effect almost disappeared. Furthermore, when fructose was present in the luminal bathing medium in place of glucose, the decrease in SCC was slight. The study suggests that the reduction in SCC is in part attributable to inhibition of glucose-dependent $\mathrm{Na}$ transport.

\section{REFERENCES AND NOTES}

1. Asano, T.: Metabolic disturbances and short-circuit current across intestinal wall of rat. Amer. J. Physiol., 207: 415 (1973).

2. Beratis, N. G., Conover, J. H., Conod, E. J., Bonforte, R. J., and Hirschhorn, K.: Studies on ciliary dyskinesia factor in cystic fibrosis. III. Skin fibroblasts and cultured amniotic fluid cells. Pediat. Res., 7: 958 (1973).

3. Bowman, B. H., Lockhart, L. H., and McCombs, M. L.: Oyster cilia inhibition by cystic fibrosis factor. Science, 164: 325 (1969).

4. Bowman. B. H., McCombs, M. L., and Lockhart. L. H.: Cystic fibrosis: Characterization of the inhibitor to ciliary action in oyster gills. Science, 167: 871 (1970).

5. Brown, G. A., Oshin, A.. Goodchild. M. C., and Anderson, C. M.: Inhibition of sugar transport by plasma from cystic-fibrosis patients. Lancet ii: 639 (1971).

6. Kaiser, D., Drack, E., and Rossi, E.: Inhibition of net sodium transport in single sweat glands by sweat of patients with cystic fibrosis of the pancreas. Pediat. Res., 5: 167 (1971).

7. Lockhart, L. H., and Bowman, B. H.: Assay for detection of the cystic fibrosis gene. Texas Rep. Biol. Med., 3I(4): 631 (1973).

8. Mangos, J. A., and McSherry, N. R.: Sodium transport: Inhibitory factor in sweat of patients with cystic fibrosis. Science, 158: 135 (1967).

9. Morine, C. L., Desjeux, J. F., and Anthier, L.: Effect of saliva and serum from patients with cystic fibrosis on intestinal uptake of amino acids in rat. Biomedicine, 19: 133 (1973).

10. Schultz, S. G., and Zalusky, R.: Ion transport in isolated rabbit ileum. I. Short-circuit current and Nafluxes. J. Gen. Physiol., 47: 567 (1964).

11. Spock, A., Heick, H. M. C., Cress, H., and Logan, W. S.: Abnormal serum factor in patients with cystic fibrosis of the pancreas. Pediat. Res., I: 173 (1967).

12. Taussig, L. M., and Gardner, J. D.: Effects of saliva and plasma from cystic fibrosis patients on membrane transport. Lancet, i: 1367 (1972).

13. Ussing, H. H., and Zerohn, K.: Active transport of sodium as the source of electric current in the short-circuited isolated frog skin. Acta Physiol. Scand. 23: $110(1951)$

14. Wood, R. E., and di Sant'Agnese, P. A.: Bioassays of cystic-fibrosis factor, Lancet ii: 1452 (1973).

15. This work was supported by a grant from the Hearst Foundation, the Ullmann Foundation, and the Ina Sue Perlmutter Fund.

16. Requests for reprints should be addressed to: H. Shwachman, M.D., Ph.D. Professor of Pediatrics, The Children's Hospital Medical Center, 300 Longwood Ave., Boston, Mass. 02115 (USA)

17. Accepted for publication August 14, 1975. 